1843. Humphreys. British Moths, Vol. I.

1869. Lintner. 23rd Rep. State Cabinet of New York, p. 214. 1916. Mosher. Bull. Illinois State Lab. of Nat. Hist., Vol. XII, Art. II.

\title{
AN INSECT AND LACK OF ENTOMOLOGICAL KNOWLEDGE AN IMMEDIATE CAUSE OF THE WORLD WAR.
}

By M. T. Smulyan,

U. S. Bureau of Entomology, Melrose Highlands, Mass.

"What dire offence from amorous causes springs, What mighty contests rise from trivial things!"

-Pope.

Those familiar with the beliefs of the ancient Greeks doubtless recall the highly fascinating bit of tradition dealing with Peleus and Thetis and the events which grew out of their marriage; how Peleus, King of Thessaly, wooed and finally overcame the scruples of the divine Thetis; how that mortal, in order to please his bride, invited the gods of Olympus to attend the nuptial rites and festivities on Mount Pelion; how the vindictive Discordia, previously expelled from heaven for sowing dissension and stirring up strife, in revenge, for not having been included among those invited, threw an apple in their midst, with the inscription, "To the most beautiful"; how this aroused the envy and jealousy of the proud and powerful divinities, Juno, Venus, and Minerva; how the dispute was carried for arbitrament to the shepherd Paris, son of Priam, King of Troy; how Paris decided in favor of Venus who offered the most tempting bribe, that of the fairest woman as wife; how later, with the assistance of the goddess, he contrived to visit the court of Menelaus, King of Sparta, husband of Helen; how the base prince then, violating all laws of hospitality and honor, carried the beautiful Helen away to Troy; and, finally, how all Greece rose to avenge the insult and the wrong.

Thus did a mere apple cause that mighty commotion, the Trojan War.

Historians and others interested in tracing the cause and origin of the late war, the great human convulsion of modern times, 
appear to be generally agreed that the fundamental causes are to be found in pre-war Germany's need for expansion, in the pressure of democratic ideas upon her autocratic régime, in the doctrine of the Superman and the ambition for world conquest, in the rivalry for trade routes and world trade, etc., etc., and that the conflict was precipitated by Austro-Serbian friction and, directly, by the assassination of the Austrian archduke. But alas for our limited human understanding! Our historians and scholars have apparently completely overlooked one of the most important and immediate facts in the chain of causation, namely, the fatal activities of an insect - an object infinitely more mischievous if far more insignificant and less attractive than Discordia's apple - a parasite (species unfortunately not known). I am unable to state at the present moment how this extremely important discovery came to be made or through what channels the intelligence reached this country; whether it is to the credit of some able press correspondent, or whether it is due to the Red Cross or American Medical Mission. The fact is inseparably bound up with a most pathetic occurrence- as pathetic as its effects were far-reaching and terrible - of which the following is the briefest outline: In a village in the interior of Serbia there lived a maiden who was loved passionately by a youth of the same village. But while she apparently accepted his, her own love, strange as it may seem, focused upon a beautiful, little, caged bird which she possessed and which she prized above all things. In the course of time, however, an insect parasite attacked the bird and killed it. The gentle girl, affected to the depths of her inmost being by the loss, developed fever and after a short illness died. The ardent youth, her lover, half-crazed by the event, rushed away from the village, the scene of his tragic misfortune, and out into the world. Some time later, in another part of the country, he became a member of an extreme patrioticrevolutionary organization and very shortly afterwards, at Sarajevo, assassinated Archduke Franz Ferdinand of Austria. The last, as is known, led to Austria's ultimatum to Serbia and to the war.

The conclusion (or lesson) is, of course, clear. Had there been sufficient entomological knowledge in that Serbian town to diagnose the bird's malady and to devise proper remedial measures, the world war with all its attendant horrors might have been averted. 

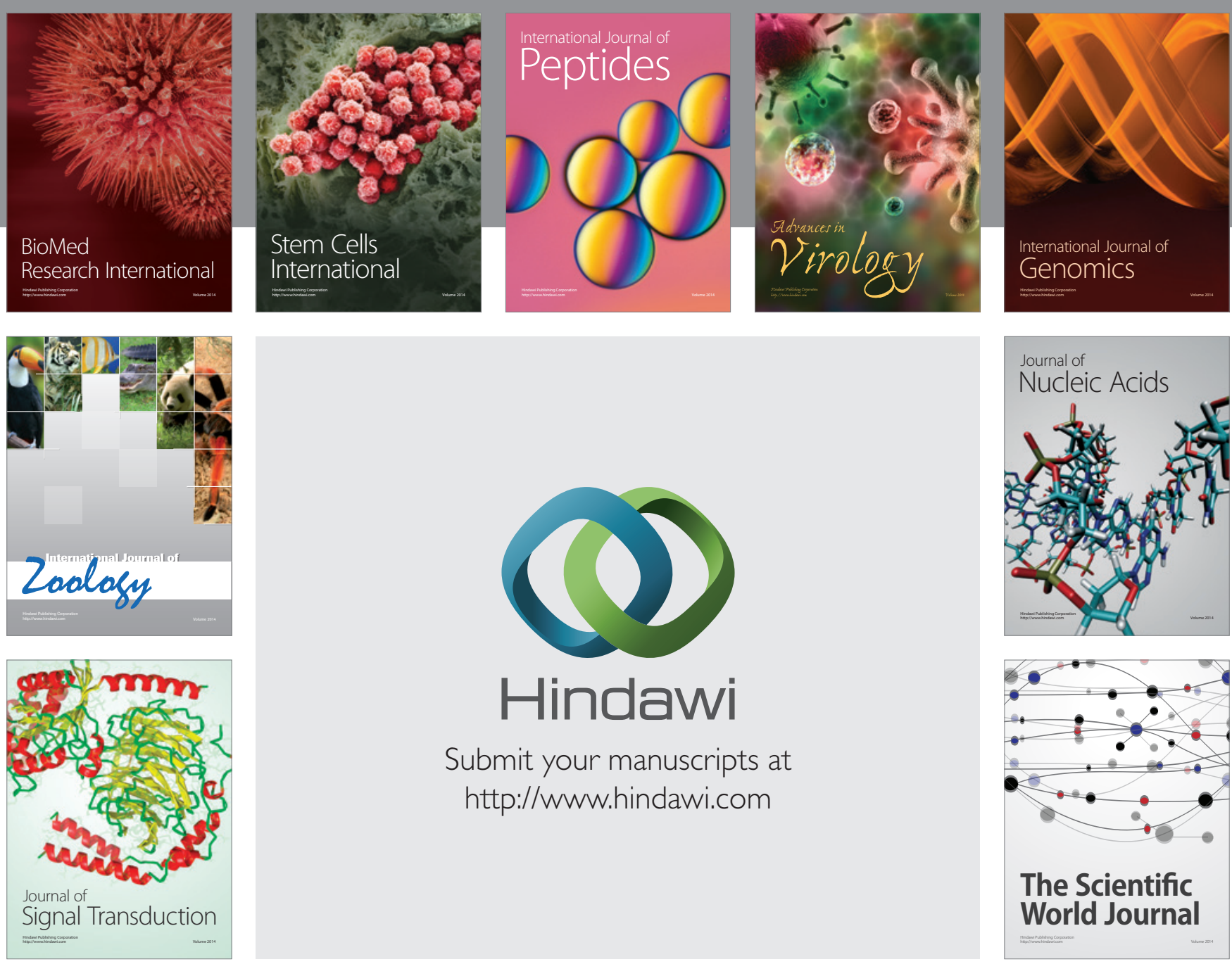

Submit your manuscripts at

http://www.hindawi.com
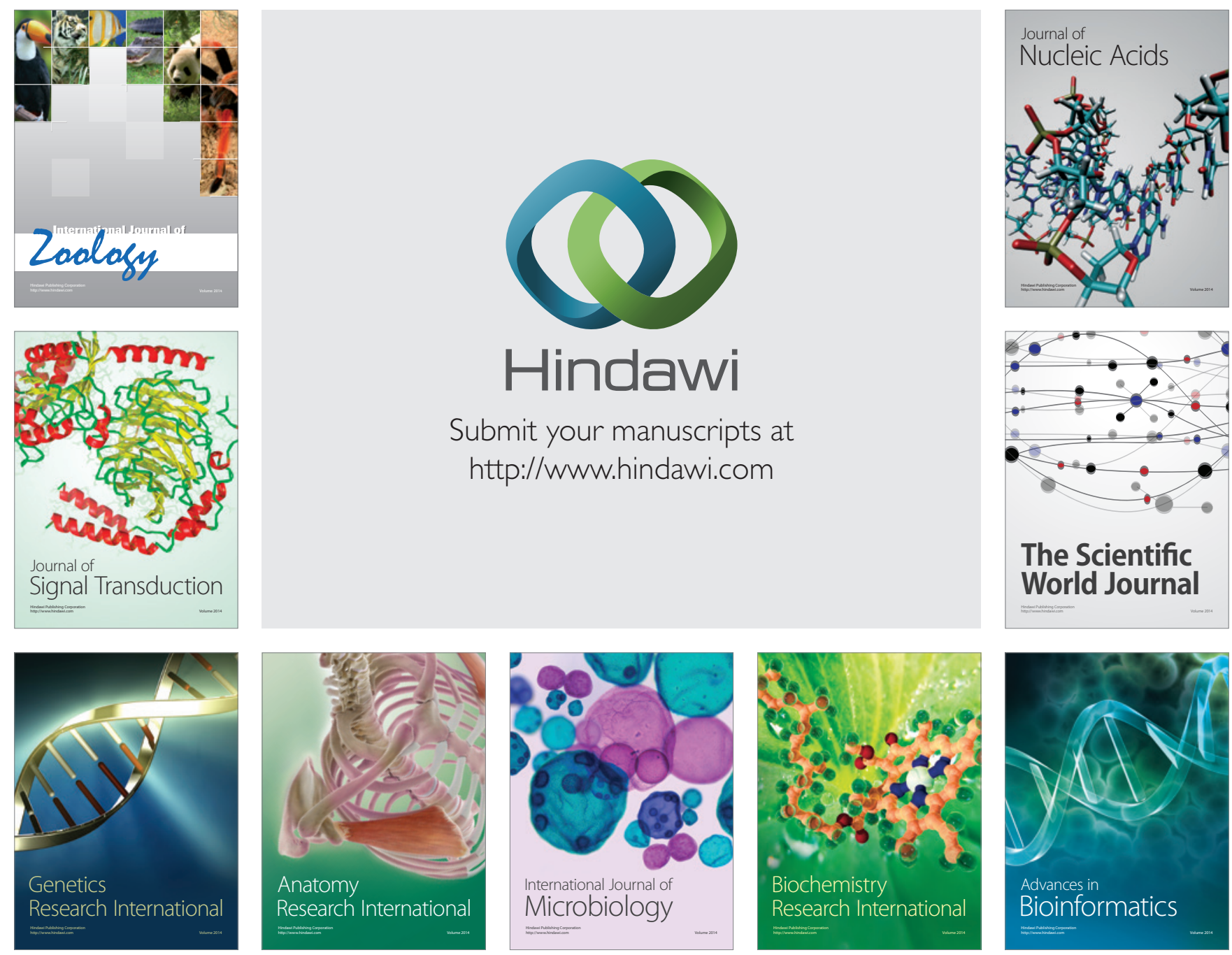

The Scientific World Journal
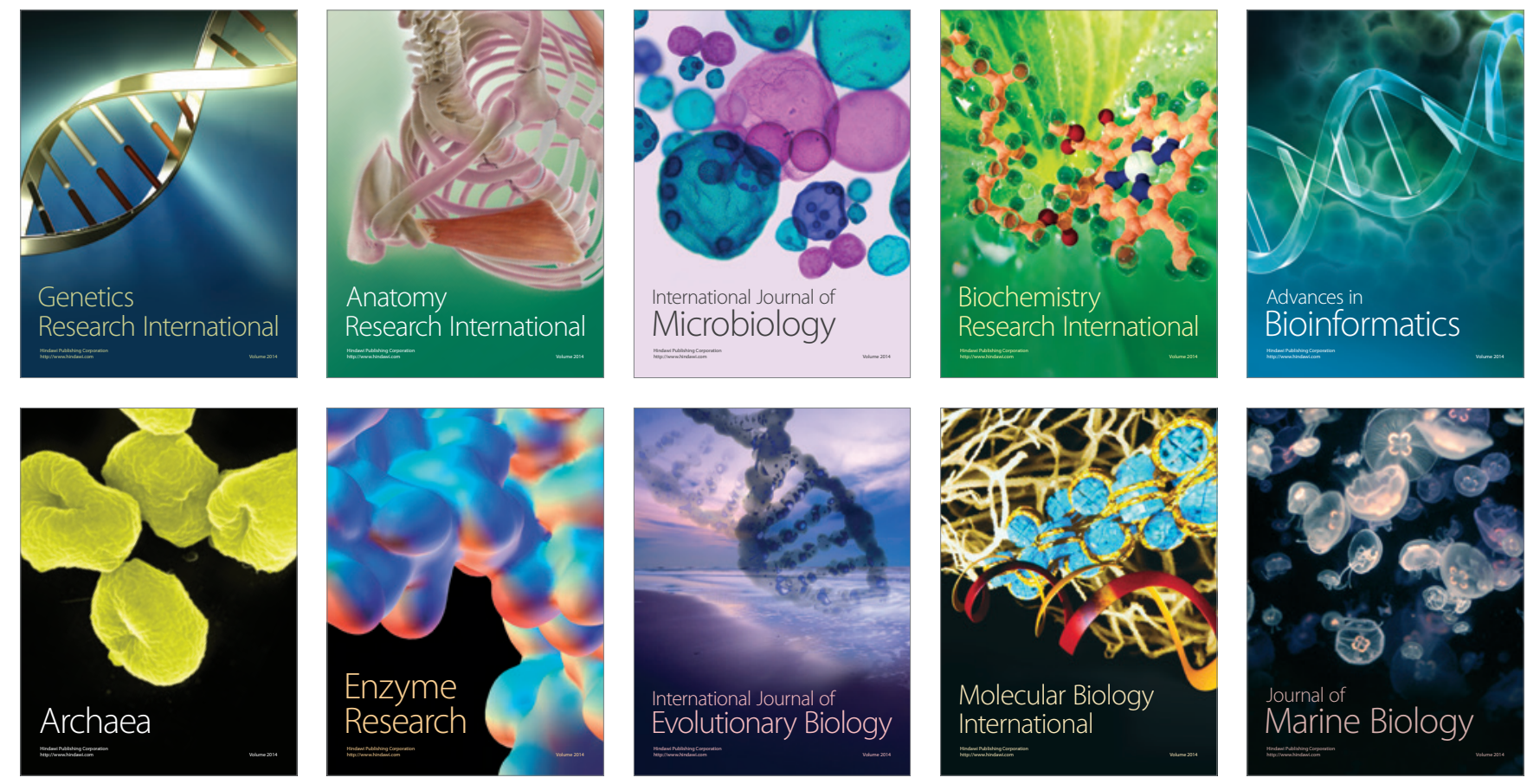